\title{
PENGARUH WAKTU INKUBASI PADA PROSES SEXING SPERMA BERBASIS GLUTATHIONE TERHADAP MOTILITAS DAN MEMBRAN PLASMA UTUH CHILLED SEMEN DOMBA LOKAL
}

\author{
A. Yusrina ${ }^{1 a}$, N. Solihati ${ }^{2}$, dan N. Hilmia ${ }^{2}$ \\ ${ }^{I}$ Program studi Reproduksi Ternak, Pascsarjana Fakultas Peternakan Universitas Padjdjaran \\ ${ }^{2}$ Staf Pengajar Fakultas Peternakan Universitas Padjdjaran \\ aemail : annisaayus@gmail.com
}

\begin{abstract}
Abstrak
Penelitian ini bertujuan untuk mengetahui pengaruh waktu inkubasi pada proses sexing sperma berbasis glutathione terhadap motilitas dan membran plasma untuh (MPU) chilled semen domba lokal. Proses pemisahan sperma $\mathrm{X}$ dan $\mathrm{Y}$ dilakukan dengan menggunakan metode kolom bovine serum albumin (BSA). Penelitian ini merupakan penelitian eksperimental menggunakan Rancangan Acak Kelompok (RAK) dengan tiga perlakuan yaitu, 45 menit (T1), 60 menit (T2) dan 75 menit (T3). Data dianalisis menggunakan analisis ragam dan diikuti dengan uji lanjut berganda Duncan. Materi yang digunakan adalah semen segar domba lokal dengan motilitas sperma $\geq 70 \%$ dan glutathione sebanyak $5 \mathrm{mM}$. Hasil penelitian menunjukan bahwa persentase motilitas tertinggi pada fraksi atas (sperma X) dan fraksi bawah (sperma Y) terdapat pada perlakuan T1 (69,73\% dan 68,82\%) diikuti oleh T2 (66,40\% dan 64,55\%) dan T3 (57,90\% dan 57,65\%). Selain itu, hasil penelitian menunjukan bahwa persentase MPU sperma tertinggi pada fraksi atas dan fraksi bawah terdapat pada T1 $(75,00 \%$ dan $71,33 \%)$, diikuti oleh T2 $(69,92 \%$ dan $68,42 \%)$ dan T3 $(66,92 \%$ dan $65,58 \%)$. Hasil penelitian dapat disimpulkan bahwa waktu inkubasi 45 menit merupakan waktu inkubasi yang optimum pada proses sexing sperma berbasis glutathione, sehingga motilitas dan MPU chilled semen sexing domba lokal dapat dipertahankan.
\end{abstract}

Kata Kunci: waktu in kubasi, sexing sperma, glutathione, semen domba

\begin{abstract}
The aim of this study was to examine the effect of incubation time on sexing process based on glutathione to the motility and Intact Plasma Membrane (IPM) of chilled ram semen. The separation of $X$ and $Y$ sperm conducted by using BSA method. This research was experimental research using completely randomized design (CRD) with three treatment namely, 45 minutes (T1), 60 minutes (T2) and 75 minutes (T3). Data were analyzed using Anova followed by Duncan's multiple range test. Material used in this research was the fresh semen from ram with sperm motility $\geq 70 \%$ and $5 \mathrm{mM}$ of glutathione. The result of this research showed that the highest percentage of motility in upper and bottom fraction belong to $T 1$ (69.73\% and 68.82\%), followed by $T 2(66.40 \%$ and $64.55 \%)$ and T3(57.90\% and $57.65 \%)$. In addition, the result of this research that the highest percentage of IPM in upper and bottom fraction belong to $T$ (75.00\% and $71.33 \%)$, followed by T2(69.92\% and68.42\%) and $T 3(66.92 \%$ dan $65.58 \%)$. It can be concluded that the incubation time of 45 minute is the optimum time on sexing process based on glutathione so that the motility and IPM of chilled ram semen can be maintained.
\end{abstract}

Keywords :incubation time, sperm sexing, glutathione, ram semen

\section{Pendahuluan}

Teknologi sexing sperma merupakan teknologi yang dapat membantu menghasilkan keturunan dengan jenis kelamin sesuai yang diinginkan, melalui proses pemisahan antara sperma pembawa kromosom $\mathrm{X}$ dan sperma pembawa kromosom Y. Teknik sexing sperma dapat dilakukan dengan menggunakan metode kolom Bovine Serum Albumin (BSA). Prinsip pada metode kolom BSA yaitu pemisahan sperma berkromosom $\mathrm{X}$ dan sperma berkromosom $\mathrm{Y}$ berdasarkan pada perbedaan 
kecepatan bergerak (motilitas) menembus kolom. Keberhasilan proses pemisahan sperma $\mathrm{X}$ dan sperma $\mathrm{Y}$ dengan metode ini dipengaruhi oleh beberapa faktor, salah satunya yaitu lama atau waktu proses inkubasi sperma. Waktu inkubasi yang terlalu singkat akan menghasilkan proporsi sperma $\mathrm{X}$ dan sperma $\mathrm{Y}$ yang sedikit, sedangkan waktu inkubasi terlalu lama dapat mengakibatkan peningkatan kerusakan pada sel sperma sehingga menurunkan kualitasnya.

Proses inkubasi diketahui dapat meningkatkan produksi radikal bebas yang sangat berbahaya bagi sel sperma. Membran plasma sperma mengandung banyak asam lemak tak jenuh ganda atau Polyunsaturated Fatty Acid (PUFA) yang sangat rentan bereaksi dengan radikal bebas. PUFA merupakan komponen utama membran sperma dalam menjaga dan mempertahankan kondisi fisiologis sperma untuk bertahan hidup. Penggunaan glutathione pada semen domba dapat membantu mempertahankan kualitas sperma dari kerusakan radikal bebas selama proses sexing sperma dan bahkan selama proses penyimpanan semen pada suhu $5{ }^{\circ} \mathrm{C}$ (ekuilibrasi). Penelitian ini bertujuan untuk mengetahui pengaruh waktu inkubasi pada proses sexing sperma berbasis glutathione terhadap motilitas dan membran plasma utuh chilled semen domba lokal

\section{Bahan dan Metode}

Penelitian dilakukan pada bulan Maret 2018 di Laboratorium Reproduksi Ternak dan Inseminasi Buatan, Faultas peternakan, UNPAD, Jatinangor. Materi yang digunakan dalam penelitian ini yaitu semen domba lokal berumur 3 tahun. Semen ditampung dari domba jantan dengan menggunakan vagina buatan, kemudian semen segar di evaluasi secara makroskopis dan mikroskopis. Semen yang memenuhi standar (kualitas baik) dibagi menjadi tiga tabung dan diencerkan 1: 4 dengan larutan Brackett Oliphant (BO) yang telah ditambahkan $5 \mathrm{mM}$ glutathione, kemudian dilakukan proses sexing sperma. Media yang digunakan pada proses sexing sperma yaitu Bovine Serum Albumin (BSA) dengan konsentrasi kolom BSA $5 \%$ dan $10 \%$.

Semen yang telah diencerkan kemudian diletakkan di atas permukaan kolom BSA dan di inkubasi pada suhu $37^{\circ} \mathrm{C}$. Proses inkubasi terdiri dari tiga waktu inkubasi yaitu 45 menit (T1), 60 menit (T2) dan 75 menit (T3), masing-masing perlakuan diulang sebanyak enam kali. Setelah proses inkubasi, sperma dikoleksi dari masing-masing kolom BSA 5\% (sperma X/betina) dan 10\% (sperma Y/jantan) dan disimpan didalam tabung untuk kemudian disentrifugasi di dalam medium BO selama 10 menit dengan kecepatan $1800 \mathrm{rpm}$. Pelet sel sperma kemudian ditambahkan dengan pengencer tris-kuning telur sebanyak $1 \mathrm{ml}$ dan disimpan disuhu $5{ }^{\circ} \mathrm{C}$ selama 3 jam, kemudian di evaluasi kualitasnya secara mikroskopis meliputi motitas dan membran plasma utuh (MPU).

Evaluasi motilitas menggunakan kamar hitung neubauer, sedangkan MPU dievaluasi menggunakan larutan HOS test. Pada evaluasi MPU sperma yang diamati sebanyak 200 sel sperma. Data dianalisis menggunakan ANOVA dan Uji berganda Duncan.

\section{Hasil dan Diskusi \\ Kualitas Semen Segar Domba Lokal}

Evaluasi kualitas pada semen segar dilakukan untuk menentukan kelayakan semen sebelum proses sexing sperma. Evaluasi dilakukan secara makroskopik maupun mikroskopik. Warna, konsistensi dan $\mathrm{pH}$ hasil dari pengamatan sperma segar domba lokal yang digunakan menunjukan hasil yang baik yaitu warna krem (putih susu), konsistensi kental dan rataan $\mathrm{pH}$ 6,8. Volume semen segar domba lokal memiliki kisaran antara 0,8-1 ml, dengan rata-rata volume $0,95 \mathrm{ml}$, kemudian rataan konsentrasi sperma total yang didapat masih normal yaitu sebesar $321,8 \times 10^{7} / \mathrm{ml}$ dengan rataan motilitas sebesar $83,3 \%$. Kualitas semen pada penelitian ini tidak berbeda jauh dengan hasil penelitian Kewilaa, dkk (2013) bahwa rata-rata volume semen domba ekor tipis yaitu $0,99 \mathrm{ml}$, konsentrasi total $3620,7 \times 10^{6} / \mathrm{ml}$ dengan rataan motilitas sebesar 75,36\%. Selain itu, rataan MPU pada semen segar yang digunakan yaitu sebesar $83,2 \%$. Berdasarkan hasil pengamatan menunjukkan bahwa semen segar domba lokal yang digunakan pada penelitian ini memiliki kualitas yang baik, sehingga dapat disimpulkan bahwa semen domba tersebut memenuhi persyaratan untuk digunakan penelitian lebih lanjut. 
Tabel 1. Rataan Motilitas Chilled Semen Sexing Domba Lokal

\begin{tabular}{ccc}
\hline \multirow{2}{*}{ Perlakuan } & \multicolumn{2}{c}{ Fraksi } \\
\cline { 2 - 3 } & Atas & Bawah \\
\hline T1 & $69,73 \pm 2,00^{\mathrm{a}}$ & $68,82 \pm 2,00^{\mathrm{a}}$ \\
T2 & $66,40 \pm 2,14^{\mathrm{b}}$ & $64,55 \pm 1,91^{\mathrm{b}}$ \\
T3 & $57,90 \pm 1,45^{\mathrm{c}}$ & $57,65 \pm 2,14^{\mathrm{c}}$ \\
\hline
\end{tabular}

Superskrip (a, b, c) yang berbeda pada kolom yang sama menunjukkan perbedaan yang nyata $(\mathrm{P}<0,05)$

\section{Pengaruh Waktu Inkubasi terhadap Motilitas Chilled Semen Domba Lokal \\ Motilitas merupakan salah satu} indikator utama dalam menentukan kualitas semen. Rataan persentase motilitas pada sperma sexing dengan tiga waktu inkubasi yang berbeda setelah proses ekuilibrasi disajikan pada Tabel 1.

Berdasarkan hasil anova bahwa perbedaan waktu inkubasi berpengaruh nyata $(\mathrm{P}<0,05)$ terhadap persentase motilitas sperma pada fraksi atas (sperma $\mathrm{X}$ ) dan sperm fraksi bawah (sperma Y). Hasil analisis duncan menunjukan persentase motilitas pada semua perlakuan berbeda nyata. Persentase motilitas sperma $\mathrm{X}$ dan sperma $\mathrm{Y}$ pada perlakuan T1 memiliki persentase lebih tinggi $(\mathrm{P}<0,05)$ dibandingkan dengan perlakuan $\mathrm{T} 2$ dan $\mathrm{T} 3$. Penurunan motilitas pada perlakuan T2 dan T3 disebabkan oleh waktu inkubasi yang terlalu lama, sehingga meningkatkan terjadinya kerusakan pada sperma. Menurut Storey (2008) selama proses inkubasi terjadi peningkatan kadar hidrogen peroksida $\left(\mathrm{H}_{2} \mathrm{O}_{2}\right)$ yang memiliki sifat toksik bagi sel sperma serta merusak membran plasma, sehingga menurunkan motilitas sperma. Berdasarkan penelitian Sunarti, dkk (2016) bahwa persentase motilitas sperma sapi setelah sexing dengan waktu inkubasi 20 menit pada lapisan atas maupun bawah (68,5\% dan 60,27\%) lebih tinggi dibandingkan dengan waktu inkubasi 35 menit $(66,25 \%$ dan $60 \%)$ dan 50 menit $(65 \%$ dan 52,5\%). Selain itu, berdasarkan penelitian Solihati, dkk (2017) persentase motilitas yang lebih tinggi pada sperma X kambing etawah setalah sexing yaitu pada waktu inkubasi 45 menit $(75,89 \%)$, sedangkan pada waktu inkubasi 60 menit dan 75 menit mengalami penurunan, persentase motilitas yang dimiliki yaitu $70,57 \%$ dan $68,26 \%$. Hasil persentase motilitas pada penelitian ini lebih rendah dikarenakan pengamatan motilitas dilakukan setalah penyimpanan selama 3 jam pada suhu $5^{\circ} \mathrm{C}$.
Radikal bebas seperti radikal hidrogen peroksida $\left(\mathrm{H}_{2} \mathrm{O}_{2}\right)$ diproduksi sel sperma secara alami karena sangat dibutuhkan dalam proses kapasitasi dan motilitas sperma, akan tetapi jumlahnya yang berlebihan dapat menginisiasi terjadinya peroksidasi lipid (Khotari, dkk., 2010). Proses peroksidasi lipid secara terus menerus pada sel sperma akan merusak membran plasma bahkan menyebabkan hilangnya komponen PUFA pada membran, fungsi enzim dan transporter membran yang terlibat dalam proses inisiasi motilitas sperma (Nissen dan Kreysel., 1983; Hsieh, dkk., 2006). Membran plasma ekor sperma mengandung banyak kanal ion terutama kanal ion $\mathrm{Ca}^{2+}$, kanal ion $\mathrm{K}^{+}$,dan kanal ion $\mathrm{Na}^{+}$yang dibutuhkan dalam memicu pergerakan flagellum sperma (Asmarinah, 2010). Berdasarkan hal tersebut dapat dikatakan bahwa peroksidasi lipid pada membran dapat menganggu proses transportasi kanal ion tersebut kedalam membran sel, yang akhirnya menghambat motilitas sperma.

Proses sexing sperma dengan menggunakan glutathione dapat membantu mempertahankan motilitas sperma baik setelah proses sexing maupun setelah penyimpanan pada suhu $5{ }^{\circ} \mathrm{C}$ selama $3 \mathrm{jam}$. Menurut hasil penelitian Anggrimani dkk (2018) menyatakn bahwa penggunaan $5 \mathrm{mM}$ glutathione pada pengencer semen beku merupakan konsentrasi yang cukup baik menginisiasi fungsi mitokondria yang secara langsung dapat meningkatkan tingkat motilitas sperma. Glutathione merupakan antioksidan yang berperan dalam mencegah dan meredam radikal bebas untuk merusak membran sel (Winarsi, 2007). Glutahione akan bekerjasama dengan antioksidan alami yaitu glutathione peroxide (GPx) dalam mengubah radikal hidrogen peroksida $\left(\mathrm{H}_{2} \mathrm{O}_{2}\right)$ menjadi air $\left(\mathrm{H}_{2} \mathrm{O}\right)$, sehingga radikal tidak dapat merusak struktur membran sel sperma (Meserguer 2007).

Berdasarkan hasil penelitian perlakuan T1 (45 menit) memiliki persentase motilitas 
sperma lebih tinggi yaitu sebesar $69,7 \%$ pada sperma $X$ dan $68,8 \%$ pada sperma $Y$. Persentase motilitas pada penelitian ini sejalan dengan hasil penelitian Sianturi, dkk (2007) menyatakan bahwa sperma sexing dengan waktu inkubasi 15 menit tanpa penambahan glutathione setelah penyimpanan 2 jam memiliki persentase motilitas sebesar 55\% pada sperma $\mathrm{X}$ dan $60 \%$ pada sperma $\mathrm{Y}$, sedangkan pada sperma sexing dengan penambahan $0,5 \mathrm{mM}$ glutathione memiliki persentase yang lebih tinggi yaitu $65 \%$ pada sperma $X$ dan $63,9 \%$ pada sperma $Y$.

\section{Pengaruh Waktu Inkubasi terhadap MPU Chilled Semen Domba Lokal}

Rataan persentase MPU pada sperma sperma sexing domba dengan tiga waktu inkubasi yang berbeda setelah proses ekuilibrasi disajikan pada Tabel 2.

Berdasarkan hasil Anova perbedaan waktu inkubasi berpengaruh nyata $(\mathrm{P}<0,05)$ terhadap persentase MPU sperma $X$ maupun pada sperma $\mathrm{Y}$, sedangkan hasil analisis Duncan persentase MPU pada semua perlakuan berbeda nyata. Sejalan dengan hasil pengamatan pada motilitas, perlakuan T1 memiliki persentase MPU lebih tinggi $(\mathrm{P}<0,05)$ dibandingkan dengan perlakuan $\mathrm{T} 2$ dan T3. Berdasarkan hasil pengamatan bahwa persentase MPU yang dihasilkan pada penelitian ini setelah proses peyimpanan pada suhu $5^{\circ} \mathrm{C}$ selama 3 jam (ekuilibrasi), tidak berbeda jauh dengan hasil penelitian Solihati, dkk (2017) pada sperma sexing tanpa proses ekuilibrasi yaitu persentase MPU pada sperma $\mathrm{X}$ setelah sexing dengan waktu inkubasi 45 menit memiliki persentase MPU sebesar 75,89 $\%$ lebih tinggi $(\mathrm{P}<0,05)$ dibandingkan dengan waktu inkubasi 60 dan 75 menit yaitu masingmasing memiliki persentase MPU sebesar $70,57 \%$ dan $68.26 \%$. Hasil penelitian menunjukkan terjadi penurunan persentase MPU seiring dengan adanya peningkatan waktu inkubasi. Menurut Olmo dkk, (2014) bahwa waktu inkubasi yang terlalu lama memicu peningkatan produksi radikal bebas. Radikal bebas yang berlebihan menyebabkan sperma mengalami peroksidasi lipid yang dapat merusak keutuhan membran plasma. Membran plasma yang rusak dapat menganggu proses metabolisme sperma dalam menghasilkan energi untuk pergerakannya (motilitas). Fosfolipid membran sel sperma domba diketahui banyak mengandung PUFA yang sangat rentan terhadap serangan radikal bebas. Docosahexaenoic acid merupakan salah satu komponen PUFA yang paling aktif bereaksi dengan radikal bebas bahkan memiliki tingkat pembentukan peroksidasi lipid dan senyawa aldehid paling tinggi dibandingkan komponen lainnya (Else dan Kraffe, 2015). Peningkatan peroksidasi lipid dan produksi senyawa aldehid seperti malondialdehyde (MDA) dapat mengakibatkan tingginya kerusakan membran, penurunan fluiditas dan meningkatkan permeabilitas (Kothari, dkk., 2010).

Semakin lama waktu inkubasi maka semakin banyak pula radikal bebas yang dihasilkan sperma. Radikal bebas merupakan produk sampingan hasil metabolisme sperma. Proses metabolisme semakin meningkat seiring dengan adanya peningkatan suhu yang dialami sel sperma (Susilawati, 2011; Yuliani dan Lukman, 2013). Penggunaan glutathione pada pengencer selama proses sexing dan penyimpanan pada suhu $5{ }^{\circ} \mathrm{C}$ dapat membantu menstabilkan struktur membran sperma dengan cara meminimalkan pembentukan radikal peroksida dalam reaksi peroksidasi lipid. Menurut hasil penelitian Solihati, dkk (2018) menyatakan bahwa penambahan $5 \mathrm{mM}$ glutathione pada pengencer semen domba dapat mempertahankan kualitas MPU sperma selama proses ekuilibrasi dibandingkan dengan pengencer semen tanpa penambahan glutathione. Glutathione adalah senyawa tripeptida yang terdiri dari asam amino glisin, sistein dan asam glutamat, diketahui bahwa kandungan sulfidril pada glutathione akan meredam aktivitas radikal bebas seperti radikal hidrogen peroksida $\left(\mathrm{H}_{2} \mathrm{O}_{2}\right)$ dan radikal hidroksil yang dapat memicu terjadinya peroksidasi lipid. Radikal hidrogen peroksida $\left(\mathrm{H}_{2} \mathrm{O}_{2}\right)$ yang terbentuk akan diubah oleh antioksidan katalase, kemudian pada waktu yang bersamaan glutathione dan glutathione peroxide (GPx) saling bekerjasama dalam mengubah radikal $\mathrm{H}_{2} \mathrm{O}_{2}$ melalui sistem yang kompleks (Halliwell \& Gutteridge 1999; Winarsi 2007). 
Tabel 2. Rataan MPU Chilled Semen Sexing Domba Lokal

\begin{tabular}{ccc}
\hline \multirow{2}{*}{ Perlakuan } & \multicolumn{2}{c}{ Fraksi } \\
\cline { 2 - 3 } & Atas & Bawah \\
\hline T1 & $75,00 \pm 2,66^{\mathrm{a}}$ & $71,33 \pm 1,32^{\mathrm{a}}$ \\
T2 & $69,92 \pm 2,61^{\mathrm{b}}$ & $68,42 \pm 1,85^{\mathrm{b}}$ \\
T3 & $66,92 \pm 1,62^{\mathrm{c}}$ & $65,58 \pm 1,20^{\mathrm{c}}$ \\
\hline
\end{tabular}

Superskrip $(a, b, c)$ yang berbeda pada kolom yang sama menunjukkan perbedaan yang nyata $(\mathrm{P}<0,05)$

\section{Kesimpulan}

Penggunaan waktu inkubasi 45 menit pada proses sexing sperma berbasis antioksidan merupakan waktu inkubasi yang optimal untuk menghasilkan motiltas dan MPU chilled semen domba lokal yang baik. Penggunaan glutathione memberikan perlindungan pada sel sperma sehingga kualitas chilled semen domba lokal dapat dipertahankan.

\section{Ucapan Terimakasih}

Penulis mengucapkan terima kasih kepada Bapak Kikin, Bapak Tohan dan rekan-rekan di Laboratorium Reproduksi Ternak dan Inseminasi Buatan, Fakultas Peternakan Universitas Padjadjaran yang telah membantu pelaksanaan penelitian ini.

\section{Daftar Pustaka}

Angrimani, D.S.R., M. Nichi., M.M. Brito., G.K.V. Kawai., B.R. Rui., dan J.D.A. Losano., N.M.G. Vieira., M.C.P. Francischini., D.S.G. Cruz., N. QueirozHazarbassanov., C.O. Massoco., dan C.I. Vannucchi. 2018. The Use of Reduced Glutathione (GSH) as Antioxidant for Cryopreserved Sperm in Dogs. Arq. Bras. Med. Vet. Zootec Vol 70 No 2: 419-428

Asmarinah. 2010. Peran Molekul Kanal Ion pada Fungsi Spermatozoa. Maj Kedokteran Indonesia, Vol 60 No 8.

Else, P.L dan E. Kraffe. 2015. Docosahexaenoic and Arachidonic Acid Peroxidation: It's A within Molecule Cascade. Biochimica et Biophysica Acta 1848: 417-421

Halliwell B \& Gutteridge JMC 1999 Antioxidant defence enzymes: the glutathione peroxidase family. In: Free radicals in biology and medicine, $3^{\text {th }}$. Oxford: Oxford University Press : 140172.
Hsieh, Y.Y., C.C. Chang dan C.S. Lin. 2006. Seminal Malondialdehyde Concentration but Not Glutathione Peroxidase Activity is Negatively Correlated with Seminal Concentration and Motility. International Journal of Biological Sciences 2: 23-29.

Kewilaa, A. I., Y. S. Ondho., dan E. T. Setiatin. 2013. Pengaruh Berbagai Jenis Pengencer Air Kelapa Muda dengan Penambahan Kuning Telur yang Berbeda terhadap Kualitas Spermatozoa Semen Cair Domba Ekor Tipis (Det). Agrinimal, Vol. 3, No. 1: 1-9.

Kothari, S., A. Thompson., A. Agarwal., S.S. Du Plessis. 2010. Free Radicals: Their Beneficial and Detrimental Effects on Sperm Function. Indian Journal of Experimental Biology Vol 48: 425-435

Meseguer, M., J.A.M. Conejero., L. Muriel, A. Pellicer, J. Remohí and N. Garrido. 2007. The Human Sperm Glutathione System: A Key Role in Male Fertility and Successful Cryopreservation. Drug Metabolism Letters, 2007, Vol 1 No 2: 121-126.

Nissen H.P And H.W. Kreysel. 1983. Polyunsaturated Fatty Acids in Relation to Sperm Motility. Andrologia 15 (3): 264-269.

Olmo, E. D., A. Bisbal., O. G. Alvarez., A. M. Morales., M. Ramon., P. J. Rabadan.,L. A. Lopez., A. J. Soler., J. J. Garde., dan M. R. F. Santos. 2014. Free-radical production after post-thaw incubation of ram spermatozoa is related to decreased in vivo fertility. Journal compilation CSIRO.

Sianturi, R. G., P. Situmorang., E. Triwulanningsih dan D.A. Kusumaningrum. 2007. Pengaruh Penambahan Glutathione dan Kolesterol pada Pemisahan Spermatozoa X dan $Y$ dengan Metode Kolom Albumin Telur. Seminar 
Nasional Teknologi Peternakan dan Veteriner: 207-213.

Solihati, N., Soeparna., S. D. Rasad., dan R. Ferlianthi. 2017. Proportion and Quality of X-Y Chromosome Bearing Sperm on Diluted Semen after Incubation in Different Time of Etawah Crossbreed Goat. The $7^{\text {th }}$ International Seminar on Tropical Animal Production: 696-701.

Solihati, N., S.D. Rasad., R. Setiawan., E. N. Foziah., dan E. T. Wigiyanti. 2018. Semen Quality of Post-Thawed Local Ram's in Tris Egg Yolk extender with Different Glutathione Level. IOP Conf. Earth and Environmental Science 199.

Storey, B. T. 2008. Mammalian sperm metabolism: oxygen and sugar, friend and foe. Int. J. Dev. Biol. 52: 427-437
Sunarti, T. Saili dan L. O. Nafiu. 2016. Karakteristik Spermatozoa Sapi Bali setelah Sexing Menggunakan Metode Kolom Albumin dengan Lama Waktu Sexing yang Berbeda. JITRO Vol 1 No.1: 65-76.

Susilawati. T. 2011. Spermatologi. Universitas Brawijaya Press. Malang : 15-45.

Winarsi,H. 2007. Antioksidan Alami dan Radikal Bebas. Penerbit Kanisius. Yogyakarta

Yuliani E dan H.Y. Lukman. 2013. Aplikasi Sperma Sexing Berbasis Antioksidan Terhadap Kualitas Dan Integritas Membran Serta Daya Fertilitas Induk Sapi Bali. Seminar Nasional Teknologi Peternakan dan Veteriner 13: 25-30. 